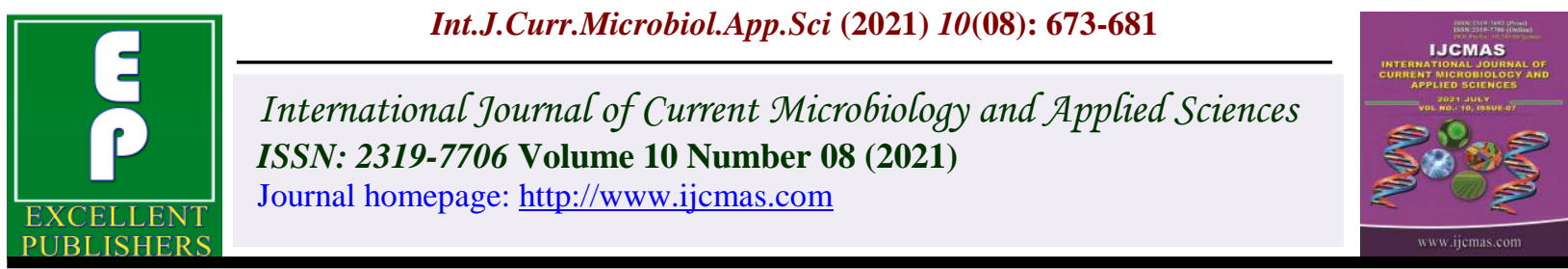

\title{
Influence of Foliar Fertilization of Nutrients on Growth, Yield and Economics of Wheat Under Sub-Tropical Rainfed Conditions
}

\author{
Vikas Abrol $^{1 *}$, Brinder Singh ${ }^{2}$, Peeyush Sharma ${ }^{1}$, A. P. Singh ${ }^{2}$ and Ravinder Chary ${ }^{3}$ \\ ${ }^{1}$ Department of Soil Science and Ag-Chemistry, Faculty of Agriculture, SKUAST-J, India \\ ${ }^{2}$ ACRA-AICRPDA, RakhDhiansar, SKUAST-J, India \\ ${ }^{3}$ Director CRIDA \& Project Coordinator (AICRPDA), ICAR-CRIDA, Hyderabad, India
}

*Corresponding author

\section{Keywords}

Foliar, nitrogen, potassium, rainfed, wheat

Article Info

Accepted:

20 July 2021

Available Online:

10 August 2021

\section{A B S T R A C T}

A field experiment was conducted from 2015 to 2016 to determine the effect of foliar application of nutrients on growth, yield and economics of wheat (Triticum aestivum. L). The study was conducted at research farm of Advanced Centre for Rainfed Agriculture under AICRPDA, Rakhdhiansar, SKUAST-Jammu. Seven treatments viz: $\mathrm{T}_{1}$ : Control (No spray), $\mathrm{T}_{2}$ : Foliar spray of $0.5 \% \mathrm{~K}$ solution in water $\left(\mathrm{KNO}_{3}\right), \mathrm{T}_{3}: \mathrm{T}_{2}+$ Foliar spray of $0.5 \% \mathrm{~N}$ solution in water (Urea), $\mathrm{T}_{4}$ : Foliar spray of $0.5 \% \mathrm{~K}$ solution in water $(\mathrm{KCl}), \mathrm{T}_{5}: \mathrm{T}_{4}+$ Foliar spray of $0.5 \% \mathrm{~N}$ solution in water $(\mathrm{Urea}), \mathrm{T}_{6}$ : Foliar spray of $0.5 \% \mathrm{~N}$ solution in water (Urea), $\mathrm{T}_{7}$ : Foliar spray of water were replicated thrice in a randomized complete block design (RCBD). The data of two years were pooled and statistically analyzed using analysis of variance (ANOVA) for Randomized Complete Block Design. The treatment means were tested for significance at $\mathrm{P}=0.05$. The results revealed that foliar application of nutrients resulted in significant effect on wheat grain and straw yield. Significantly higher wheat grain yield of $2224 \mathrm{~kg} \mathrm{ha}^{-1}$ was obtained in combined foliar spray of $0.5 \% \mathrm{~N}$ (urea) $+0.5 \% \mathrm{~K}(\mathrm{KCl})$ and it was statistically at par with the combined foliar spray of $0.5 \% \mathrm{~N}($ Urea $)+\mathrm{K}\left(\mathrm{KNO}_{3}\right)$ with grain yield of $2007 \mathrm{~kg} \mathrm{ha}^{-1}$. The lowest grain yield $\left(944 \mathrm{~kg} \mathrm{ha}^{-1}\right)$ was found in control. Similar trend was observed in yield contributing plant attributes. Significantly highest uptake N, P and K was recorded with the combined foliar spray of $0.5 \% \mathrm{~N}$ (urea) + $0.5 \% \mathrm{~K}(\mathrm{KCl})$ followed by $\mathrm{T} 3$ and $\mathrm{T} 6$ which were statistically at par. The highest gross return and net returns of Rs49430 and Rs $29576 \mathrm{ha}^{-1}$, respectively were obtained in foliar spray of $0.5 \% \mathrm{~N}$ (urea) $+0.5 \% \mathrm{~K}(\mathrm{KCl})$ with highest benefit:cost ratio while the lowest gross return and net returns to the tune of Rs 23992 and $\mathrm{Rs} 6087 \mathrm{ha}^{-1}$ were recorded in unfertilized control. The highest agronomic use efficiency (AUE) and apparent recovery (ARE) of nitrogen and potassium were recorded in T5. The study concluded that foliar application of $0.5 \% \mathrm{~N}$ (urea) $+0.5 \% \mathrm{~K}(\mathrm{KCl})$ played complementary role in improving crop productivity of wheat grown in rainfed conditions. 


\section{Introduction}

Wheat (Triticum aestivum L.) is the most important food crop of the world and increasing wheat productivity is a national priority to bridge the gap between production and consumption. Wheat is the predominant rabi crop grown in foothills of Shivaliks (Jamwal, 2000). Production constraints like scarcity of soil moisture during most of the crop growth periods, high erodibility (Abrol $e t$ al., 2019), low and erratic rainfall from sowing to harvesting (Abrol et al., 2008), low soil fertility (Abrol et al., 2015) high runoff water losses and high evaporation in these light textured soils results in stagnant wheat yield in rainfed areas of Jammu (Sharma et al., 2011). Among the essential nutrients needed by the plant, nitrogen and potassium play an important role as adequate supply of these nutrients greatly improves the quality and quantity of productivity especially under rainfed conditions due to regulatory role of potassium in opening and closing of stomata.

Besides soil application of nutrients, the alternative approach is to apply nutrients as foliar spray has become an established technology to enhance yield and improve quality of crop products. Foliar application also improves nutrient utilization and lower environmental pollution through reducing the amount of fertilizers added to soil (Yaseen et al., 2011). Moreover, foliar applications of nutrients in addition to basal applications are proved to be judicious, efficient and economical perspective for some crops (Gholami et al., 2011). The rainfed farming of wheat carries a risk of over-fertilization that leads to substantial economic loss with concomitant deterioration of soil fertility.

The situation is further aggravated by occurrence of recurring dry spells during critical stage of crop growth period which leads to substantial loss of crop productivity.
We hypothesized that sole or combined foliar spray of growth promoting nitrogen and osmoregulatory controlling potassium might offset the deleterious effect of dry spells during crop growth period. An investigation was undertaken to determine the influence of foliar application of nutrients on wheat crop under sub-tropical rainfed conditions of Jammu region.

\section{Materials and Methods}

\section{Experimental details}

The field experiments were conducted at the research farm of Advanced Centre for Rainfed Agriculture Research of the Sher-e-Kashmir University of Agricultural Sciences and Technology, Jammu during year 2015 - 2016 under rainfed conditions. The experimental site is representative of the rainfed ecology of foothills of Shivaliks, located at a latitude of $32^{\circ} 39^{\prime \prime}$ North and longitude of $74^{\circ} 53^{\prime \prime}$ East, at $332 \mathrm{~m}$ above mean sea level. The region experiences sub-humid climate with $1152 \mathrm{~mm}$ precipitation wherein about $75 \%$ of total precipitation occurs in the summer season from July to September. May and June are the driest period for crop growth and little precipitation occurs during the winter months of December and January. The taxonomical soil unit is an Inceptisol with a sandy loam texture. The analysis of initial soil samples taken from the experimental site at the start of the study in 2015 indicated that the surface soil from $0-15 \mathrm{~cm}$ depth had a $\mathrm{pH} 6.6$, soil organic carbon (SOC) content $2.6 \mathrm{~g} \mathrm{~kg}^{-1}$, soil $\mathrm{N} 169 \mathrm{~kg} \mathrm{ha}^{-1}, \mathrm{P} 13 \mathrm{~kg} \mathrm{ha}^{-1}$ and $\mathrm{K} 98 \mathrm{~kg} \mathrm{ha}^{-1}$. The field experiments were conducted by superimposing six foliar fertilizer treatments with an unfertilized control to the same plots every year. The treatments $\mathrm{T}_{1}$ : Control (No spray), $\mathrm{T}_{2}$ : Foliar spray of $0.5 \% \mathrm{~K}$ solution in water $\left(\mathrm{KNO}_{3}\right), \mathrm{T}_{3}: \mathrm{T}_{2}+$ Foliar spray of $0.5 \% \mathrm{~N}$ solution in water (Urea), $\mathrm{T}_{4}$ : Foliar spray of $0.5 \% \mathrm{~K}$ solution in water $(\mathrm{KCl}), \mathrm{T}_{5}: \mathrm{T}_{4}+$ 
Foliar spray of $0.5 \% \mathrm{~N}$ solution in water (Urea), $\mathrm{T}_{6}$ : Foliar spray of $0.5 \% \mathrm{~N}$ solution in water (Urea), $\mathrm{T}_{7}$ : Foliar spray of water. The sources of nitrogen, and potassium were urea and murate of potash, respectively. Foliar application of nutrients was done during real time dry spells experienced during crop growth period in addition to $100 \%$ recommended dose of fertilizers (100:66:35) except in control. The sole water spray was carried with deionized water to simulate rain water quality. The experimental plots were laid-out in a randomized block design with 3 replications having plot size of $5 \mathrm{~m} \times 3 \mathrm{~m}(15$ $\mathrm{m}^{2}$ ). Wheat crop was sown with recommended seed rate of $100 \mathrm{~kg} / \mathrm{ha}$ with row to row spacing of $22.5 \mathrm{~cm}$. Among fertilizer doses, $100 \%$ of $\mathrm{P}$ and $\mathrm{K}$ doses were applied at the time of sowing, while $\mathrm{N}$ was applied in three splits i.e., 2/3 rd of $\mathrm{N}$ at the time of sowing as basal dose and the remaining $1 / 3$ rd nitrogen as top dressing before boot stage in all treatments except control. Soil nutrients, available $\mathrm{N}$ was determined by alkaline $\mathrm{KMNO}_{4}$ method (Subbaiah and Asija, 1956), $\mathrm{P}$ was extracted from soil by $0.5 \mathrm{M} \mathrm{NaHCO}_{3}$ ( $\mathrm{pH}$ 8.5) as per the method of Olsen et al., (1954) and available $\mathrm{K}$ was extracted by $1 \mathrm{~N}$ $\mathrm{CH}_{3} \mathrm{COONH}_{4}$ (pH 7.0) as proposed by Merwin and Peech (1951); SOC content was estimated by wet digestion method of Walkley and Black (1934). Recommended cultural practices of growing wheat were followed and the plant samples of one-meter row were taken at random from the middle rows of each plot from the three replicates to measure plant height $(\mathrm{cm})$, number of tillers $\mathrm{m}^{-1}$ row length, spike length $(\mathrm{cm})$, test weight of 1000 grain (gm) at the harvest of crop. The plant samples were sampled every year after harvest and uptake of $\mathrm{N}$ was determined by modified microkjeldhal method, $\mathrm{P}$ by Vanadomolybdo Phosphoric acid yellow colour (Jackson, 1973) and $\mathrm{K}$ by Ammonium acetate method (Jackson, 1973). The uptake of nutrients was calculated by multiplying their respective nutrient contents with plant dry matter. Three foliar sprays as per treatments were applied (with $500 \mathrm{~L}$ water/ha) at crown root initiation, booting and milking stages. The data were pooled and statistically analyzed using analysis of variance (ANOVA) for randomized complete block design. The treatment means were tested for significance at $\mathrm{P}<0.05$.

The nutrient use efficiency indices were calculated as:

Agronomic use efficiency $($ AUE $)=($ Grain yield in fertilized - Grain yield in unfertilized)/Nutrient applied (1)

Apparent recovery efficiency (ARE) = (Nutrient uptake of nutrient in fertilizedNutrient uptake of nutrient in unfertilized)/Nutrient applied (2)

\section{Results and Discussion}

\section{Yield attributing components and plant uptake of nutrients}

The analysis of variance (Table 1) revealed that plant height was significantly affected by foliar application of water, $\mathrm{N}$ and $\mathrm{K}$ solutions. Maximum plant height $(103.90 \mathrm{~cm})$ was recorded in those plots which were sprayed with $0.5 \% \mathrm{~N}$ (urea) $+0.5 \% \mathrm{~K}(\mathrm{KCl})$, while minimum plant height $(76.16 \mathrm{~cm})$ was recorded in control (no spray) plots. This might be attributed to foliar application of $\mathrm{N}$ and $\mathrm{K}$ solution which increased the stem length which in turn resulted in maximum plant height in treated plots. These results are in conformity with Gul et al., (2011) and Rogalski (1994) who reported higher length of wheat with combined foliar spray of $\mathrm{N}$ and $\mathrm{K}$. The foliar application of $\mathrm{N}$ and $\mathrm{K}$ solutions had significant effect on the number of tiller $\mathrm{m}^{-1}$ row length with maximum value (111.67) recorded in plots sprayed with $0.5 \% \mathrm{~N}$ (urea) 
$+0.5 \% \mathrm{~K}(\mathrm{KCl})$ while minimum number of tiller $\mathrm{m}^{-1}(65.12)$ were recorded in control (no spray) plots. This might be due to the fact that crop readily absorbs more nutrients through foliar application which in turn produced more tillers $\mathrm{m}^{-1}$. These results are in the conformity with those of Dafen et al., (1999), who reported that number of tillers $\mathrm{m}^{-1}$ increased with foliar application of potash. Narimani $e t$ al., (2010) have also reported increased the number of productive tillers with foliar spray of urea. The pooled data obtained for mean spike length per plant revealed that combined foliar application of $\mathrm{N}$ and $\mathrm{K}$ treatments were found to be significantly superior to the other treatments. Maximum mean value was recorded from combined foliar application of $0.5 \% \mathrm{~N}$ (urea) $+0.5 \% \mathrm{~K}(\mathrm{KCl})$ which was 1.25 and 1.60 times higher than water spray and control respectively. The results are in accordance with those of Wagan et al., (2017) and Jamal (2007). Analysis of the data revealed that foliar application of nutrients solution resulted in a significant increase in thousand grains weight. The combined foliar spray of $0.5 \% \mathrm{~N}$ (urea) $+0.5 \% \mathrm{~K}(\mathrm{KCl})$ resulted in significantly heavier grains (36.95 g) which was statistically at par with foliar spray of $0.5 \% \mathrm{~N}$ (urea) $+0.5 \% \mathrm{~K}\left(\mathrm{KNO}_{3}\right)$ and foliar spray of $0.5 \% \mathrm{~K}(\mathrm{KCl})$ with grain weight of $36.39 \mathrm{~g}$ and $36.12 \mathrm{~g}$ respectively while control treatment produced grains with least weight $(30.33 \mathrm{~g})$. This may be due to the provision of nutrients at later stages which might have enhanced accumulation of assimilates in the grains thus resulting in heavier grains of wheat. The results are in line with Amal et al., (2011), Khan et al., (2009) and Arif et al., (2006) who reported significant increase in thousand grains weight with foliar application of nutrients.

The uptake values obtained with combined foliar spray of $\mathrm{N}$ and $\mathrm{K}$ were almost similar however significant differences were observed when compared with sole application of $\mathrm{N}, \mathrm{K}$, water spray and control (Table 1). On average total $\mathrm{N}, \mathrm{P}$ and $\mathrm{K}$ uptake ranged from 30.36 to $73.18,8.04$ to 22.36 and 28.74 to $65.67 \mathrm{~kg} \mathrm{ha}^{-1}$ respectively. The combined foliar spray of $0.5 \% \mathrm{~N}$ (urea) $+0.5 \% \mathrm{~K}(\mathrm{KCl})$ recorded maximum uptake of nutrients over water spray and control. This might be attributed to combined foliar spray of $\mathrm{N}$ and $\mathrm{K}$ which led to increase in grain and straw production with their increased concentration in plant system. These results corroborate the findings of Arif et al., (2006). Further, significantly superior phosphorus in treatments receiving foliar nitrogen might be due to close interrelation ship between nitrogen and phosphorus metabolism in plant cell. Similar results were obtained by Kumar et al., (2015).

Crop productivity, economic returns and resource use efficiency

Grain and straw yield of wheat was significantly affected by foliar application of nutrients and water (Table 2). The highest average grain $\left(2224 \mathrm{~kg} \mathrm{ha}^{-1}\right)$ and straw yield $\left(3667 \mathrm{~kg} \mathrm{ha}^{-1}\right)$ was recorded with combined foliar spray of $0.5 \% \mathrm{~N}$ (urea) with $0.5 \% \mathrm{~K}$ $(\mathrm{KCl})$ which showed statistical parity by combined foliar spray of $0.5 \% \mathrm{~N}$ (urea) with $0.5 \% \mathrm{~K}\left(\mathrm{KNO}_{3}\right)$ and these treatments proved significantly superior to rest of the treatments. Strong (1982) and Gooding and Devies (1992) also reported increased grain yield for foliar application of $\mathrm{N}$ and $\mathrm{K}$ individually or in combinations. It might be due to beneficial effect of foliar spray of $\mathrm{N}$ and $\mathrm{K}$ that controlled their losses from the soil and facilitated easily availability to the plant which manifested in increased yield and quality of wheat grain. Further it could be attributed to better availability of nutrients at vital growth period and synthesis of carbohydrates and their translocation. Rehman et al., (2014) also reported increased grain yield for foliar application of $\mathrm{N}$ and $\mathrm{K}$, individually or in combination. 
Table.1 Effect of foliar fertilizer treatments on yield attributes and nutrient uptake in wheat (pooled mean of two years)

\begin{tabular}{|c|c|c|c|c|c|c|c|c|c|c|c|c|c|c|}
\hline \multirow[t]{2}{*}{ Treatments } & \multirow{2}{*}{$\begin{array}{l}\text { Plant } \\
\text { height } \\
(\mathrm{cm})\end{array}$} & \multirow{2}{*}{$\begin{array}{l}\text { Tillers } \\
\text { m}^{-1} \text { row } \\
\text { length }\end{array}$} & \multirow{2}{*}{$\begin{array}{l}\text { Spike } \\
\text { length } \\
(\mathrm{cm})\end{array}$} & \multirow[t]{2}{*}{$\begin{array}{l}\text { Spikelet } \\
\text { /Spike }\end{array}$} & \multirow[t]{2}{*}{$\begin{array}{c}\text { Test weight } \\
\text { (g) }\end{array}$} & \multicolumn{3}{|c|}{$\begin{array}{l}\text { Uptake N } \\
\text { kgha }^{-1}\end{array}$} & \multicolumn{3}{|c|}{ Uptake P kgha ${ }^{-1}$} & \multicolumn{3}{|c|}{ 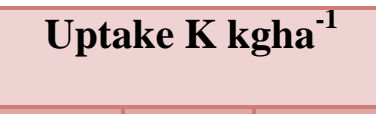 } \\
\hline & & & & & & 2015 & 2016 & Mean & 2015 & 2016 & Mean & 2015 & 2016 & Mean \\
\hline T1 & 76.16 & 65.12 & 6.19 & 5.85 & 30.33 & 30.58 & 30.14 & 30.36 & 8.18 & 7.90 & 8.04 & 26.41 & 31.08 & 28.74 \\
\hline $\mathbf{T} 2$ & 92.57 & 88.62 & 9.09 & 11.08 & 33.56 & 49.88 & 61.64 & 55.76 & 14.31 & 18.58 & 16.44 & 43.71 & 56.29 & 50.00 \\
\hline T3 & 101.94 & 108.78 & 9.72 & 12.02 & 36.39 & 59.29 & 71.62 & 65.45 & 16.59 & 20.06 & 18.33 & 49.46 & 59.37 & 54.41 \\
\hline T4 & 93.44 & 97.72 & 8.79 & 10.78 & 36.12 & 52.59 & 63.16 & 57.87 & 14.27 & 18.06 & 16.17 & 48.77 & 60.13 & 54.45 \\
\hline T5 & 103.90 & 111.67 & 10.04 & 12.52 & 36.95 & 67.70 & 78.67 & 73.18 & 20.32 & 24.40 & 22.36 & 61.01 & 70.33 & 65.67 \\
\hline T6 & 92.74 & 93.70 & 9.11 & 10.63 & 34.64 & 54.11 & 68.22 & 61.17 & 14.92 & 19.80 & 17.36 & 46.99 & 60.62 & 53.81 \\
\hline T7 & 85.91 & 81.57 & 7.97 & 9.52 & 33.72 & 44.43 & 55.50 & 49.97 & 12.03 & 15.76 & 13.90 & 38.60 & 50.81 & 44.70 \\
\hline CD $(P<0.05)$ & 6.51 & 12.94 & 1.71 & 0.71 & 1.12 & 11.46 & 7.67 & 9.56 & 2.45 & 1.73 & 2.09 & 6.83 & 6.68 & 6.76 \\
\hline
\end{tabular}

$\mathrm{T}_{1}$ : Control (No spray), $\mathrm{T}_{2}$ : Foliar spray of $0.5 \% \mathrm{~K}$ solution in water $\left(\mathrm{KNO}_{3}\right), \mathrm{T}_{3}: \mathrm{T}_{2}+$ Foliar spray of $0.5 \% \mathrm{~N}$ solution in water (Urea), $\mathrm{T}_{4}:$ Foliar spray of $0.5 \%$

$\mathrm{K}$ solution in water $(\mathrm{KCl}), \mathrm{T}_{5}: \mathrm{T}_{4}+$ Foliar spray of $0.5 \% \mathrm{~N}$ solution in water (Urea), $\mathrm{T}_{6}$ : Foliar spray of $0.5 \% \mathrm{~N}$ solution in water (Urea), $\mathrm{T}_{7}:$ Foliar spray of water.

Table.2 Effect of foliar fertilizer treatments on grain and straw yield of wheat at harvesting

\begin{tabular}{|c|c|c|c|c|c|c|}
\hline \multirow{2}{*}{ Treatment } & \multicolumn{3}{|c|}{ Grain Yield kgha-1 $^{-1}$} & \multicolumn{3}{c|}{ Straw Yield kgha $^{-1}$} \\
\cline { 2 - 7 } & $\mathbf{2 0 1 5}$ & $\mathbf{2 0 1 6}$ & Mean & $\mathbf{2 0 1 5}$ & $\mathbf{2 0 1 6}$ & Mean \\
\hline T1 & 1055 & 833 & 944 & 2209 & 2472 & 2341 \\
\hline T2 & 1614 & 1928 & 1771 & 3214 & 3461 & 3338 \\
\hline T3 & 1819 & 2194 & 2007 & 3408 & 3417 & 3413 \\
\hline T4 & 1708 & 2000 & 1854 & 3361 & 3444 & 3403 \\
\hline T5 & 2044 & 2403 & 2224 & 3756 & 3597 & 3677 \\
\hline T6 & 1742 & 2111 & 1927 & 3383 & 3694 & 3539 \\
\hline T7 & 1475 & 1736 & 1606 & 3039 & 3125 & 3082 \\
\hline CD $(\boldsymbol{P}<\mathbf{0 . 0 5})$ & 290 & 410 & 226 & 555 & 432 & 109 \\
\hline
\end{tabular}


Table.3 Effect of foliar fertilizer treatments on gross returns, net returns and benefit:cost ratio of wheat

\begin{tabular}{|c|c|c|c|c|c|c|c|c|c|}
\hline Treatment & \multicolumn{3}{|c|}{$\begin{array}{c}\text { Gross returns } \\
\text { (Rs ha }^{-1} \text { ) }\end{array}$} & \multicolumn{3}{c|}{$\begin{array}{c}\text { Net returns } \\
\text { (Rs ha }^{-1} \text { ) }\end{array}$} & \multicolumn{3}{c|}{ B:C ratio } \\
\cline { 2 - 12 } & $\mathbf{2 0 1 5}$ & $\mathbf{2 0 1 6}$ & Mean & $\mathbf{2 0 1 5}$ & $\mathbf{2 0 1 6}$ & Mean & $\mathbf{2 0 1 5}$ & $\mathbf{2 0 1 6}$ & Mean \\
\hline T1 & 25192 & 22792 & 23992 & 7392 & 4782 & 6087 & 1.42 & 1.27 & 1.35 \\
\hline T2 & 37871 & 43725 & 40798 & 18120 & 23574 & 20847 & 1.92 & 2.17 & 2.05 \\
\hline T3 & 41835 & 47681 & 44758 & 22043 & 27488 & 24766 & 2.11 & 2.36 & 2.24 \\
\hline T4 & 39924 & 44778 & 42351 & 20287 & 24741 & 22514 & 2.03 & 2.23 & 2.13 \\
\hline T5 & 47228 & 51632 & 49430 & 27591 & 31560 & 29576 & 2.41 & 2.57 & 2.49 \\
\hline T6 & 40529 & 47500 & 44015 & 20857 & 27488 & 24173 & 2.06 & 2.37 & 2.22 \\
\hline T7 & 35018 & 39410 & 37214 & 15447 & 19439 & 17443 & 1.79 & 1.97 & 1.88 \\
\hline
\end{tabular}

Fig.1

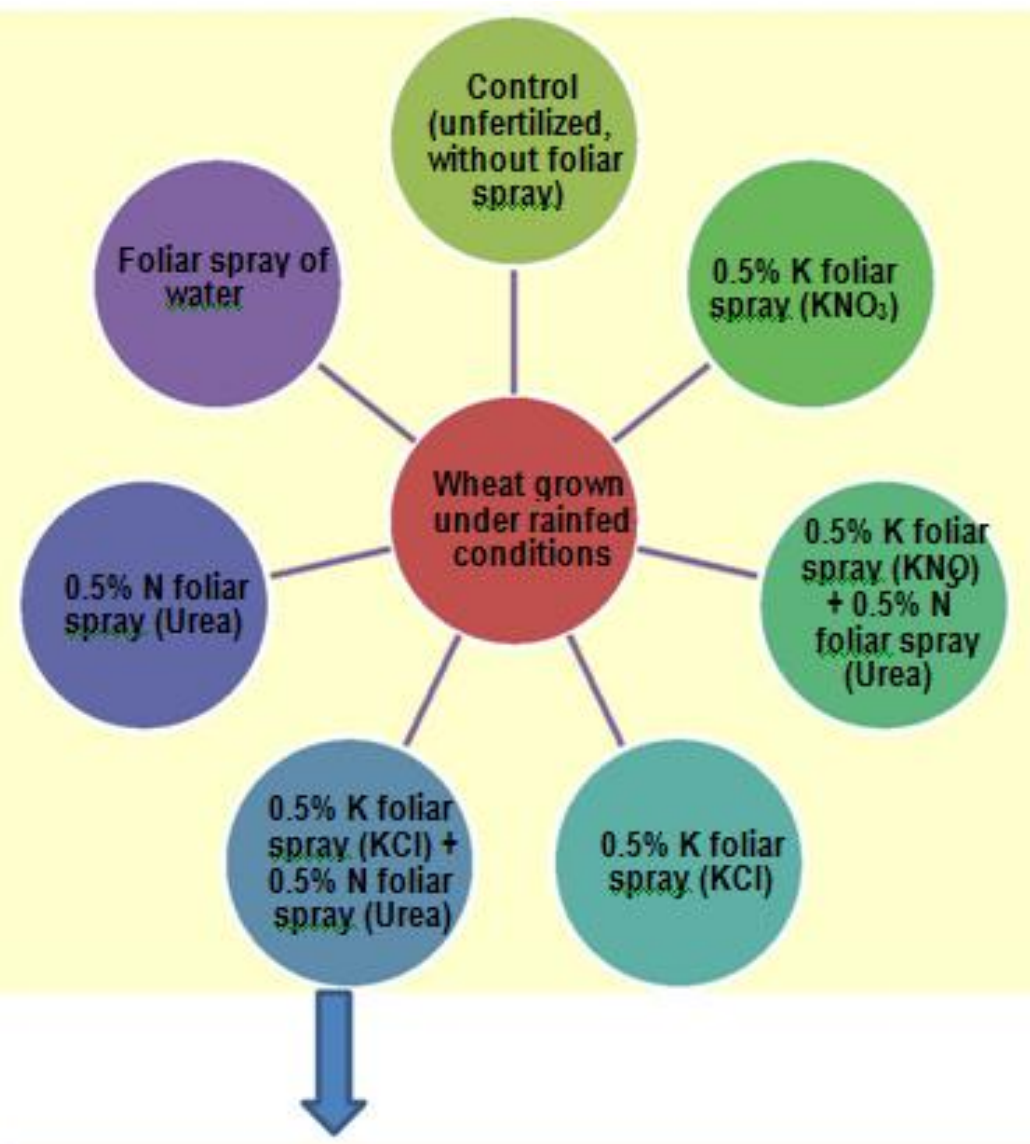

$\Rightarrow$ Improved yield contributing plant attributes, attained maximumyield, nutrient use efficiency and higher profitability

$\Rightarrow$ Efficacy of combined foliar supply of nitrogen and potassium and their complementary role in mitigating production losses by offsetting dryspells during crop growth period in rainfed wheat 
Fig.2 Effect of foliar fertilizer treatments on agronomic use efficiency (AUE) and apparent recovery efficiency (ARE) of nitrogen and potassium

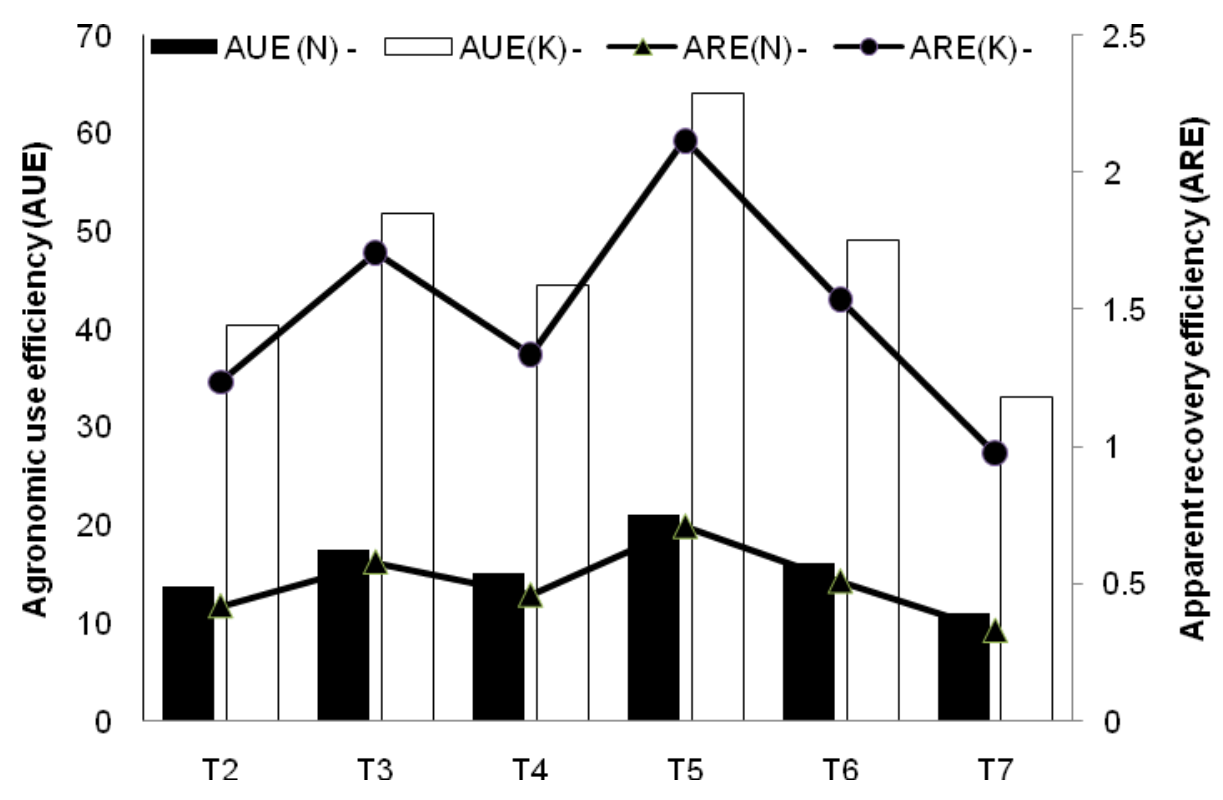

Pooled data of two years showed that combined foliar spray of $0.5 \% \mathrm{~N}$ (urea) with $0.5 \% \mathrm{~K}(\mathrm{KCl})$ gave remarkably higher net monetary returns (29576 $\mathrm{Rs} \mathrm{ha}^{-1}$ ) and benefit: cost ratio (2.49) followed by combined foliar spray of $0.5 \% \mathrm{~N}$ (urea) $+0.5 \% \mathrm{~K}\left(\mathrm{KNO}_{3}\right)$, and the lowest $\mathrm{B}: \mathrm{C}$ ratio was recorded in control (Table 3). It is obvious because of higher grain and straw yield obtained under treatment, $0.5 \% \mathrm{~N}$ (urea) $+0.5 \% \mathrm{~K}\left(\mathrm{KNO}_{3}\right)$ as compared to other treatments which consequently resulted in higher net returns and benefit:cost ratio. Arif et al., (2019) and Meena et al., (2017) also reported higher monetary returns with foliar management of nutrients.

The highest agronomic use efficiency (AUE) and apparent recovery (ARE) of nitrogen was recorded in T5 which registered 1.92 and 2.15 times higher over water spray followed by T2. Similar trend was observed in AUE and ARE of potassium. This could be due to better assimilation of nutrients applied through foliar application which complemented in improving AUE and ARE. Mengel (2002) ascribed that K acts as a catalyst for enzyme activation in plant, protein synthesis, starch formation and translocation of proteins as well as the regulation of water use (osmoregulation) in the plant.

The study confirmed the complementary role of foliar supply of mineral nutrition for improving wheat yield, net monetary benefits and use efficiency of applied nutrients under rainfed conditions.

\section{References}

Abrol, V., R. K. Sharma, V. Sharma, P. Sharma, K.R. Sharma, A. Kumar and M. Sharma: Landuse impact on soil physical variability and erodibility in North Western subtropics of India. $J$. Environ. Biol., 40, 668-673 (2019).

Abrol, V., P. Sharma., G. R. Maruti. Sankar., M. Sharma., R. Chandra. And V. Sharma:Soil management effects on soil quality and crop performance in dry sub humid Inceptisols of India.Ind J Soil Cons.,43, 47-57 (2015)

Abrol, V., G. R. Maruti. Sankar., P. Sharma., 
M. Singh :Optimization of organic and inorganic nitrogen for rainfed maize (Z) in dry sub-humid Inceptisols. Ind $J$ Agro., 53, 178-83 (2008).

Amal, G. A., M. M. Tawfik and M. S. Hassanein: Foliar feeding of potassium and urea for maximizing wheat productivity in sandy soil. Aust $J$ Bas App Sci., 5,1197-03 (2011).

Arif, M., L N. Dashora., J. Choudhary., S. S. Kadam and Mohsin M: Effect of nitrogen and zinc management on growth, yield and economics of bread wheat (Triticum aestivum) varieties. Ind JAgril Sci., 89, 1664-1668 (2019)

Arif, M., M A Chohan., S. Ali., R.Gul and S.Khan: Response of wheat to foliar application of nutrients. J Agri Bio Sci, 1, 30-34 (2006).

Arif, M., M. A.Chohan, S. Ali, R. Gul and S. Khan: Response of wheat to foliar application of nutrients. J Agri Bio Sci, 1,30-34 (2006)

Dafen, T A., H. M. A.Kholi, M. G. M.Rifaat and A. E. A. Allah: Effect of foliar and soil application of potassium on yield and mineral content of wheat grains grown in sandy soils. Egyp J Agri Res.,77, 513-22(1999)

Gholami, A., Akhlaghi. S., Shahsavani. S and Farrokhi N: Effects of Urea Foliar Application on Grain Yield and Quality of Winter Wheat. Soil Sci and Pl Anal.,42, 719-727(2011).

Gooding, M J. Foliar urea fertilisation and the management of yield and quality in wheat. Int FertSoc Pro 573 (2005).

Gooding, M. J. and W. P. Devies: Foliar urea fertilization of cereals:Nut Cyc Agroeco.,32,209-222(1992).

Gosavi, A. B., K. P. Deolankar., J. S. Chaure and D. A. Gadekar:Response of wheat for NPK foliar sprays under water stress condition. Int J Chem.Std.,5,766768 (2017).

Gul, H., Said. A., B. Saeed., F. Mohammad and Ahmad I: Effect of foliar application of nitrogen, potassium and zinc on wheat growth. J Agri Bio Sci., 6:56-9 (2011).

Jackson, M. L. Soil chemical analysis. pp. 165-167. Asia publication house, Bombay (1973).

Jamal, Z and Chaudhary. M. F: Effects of soil and foliar application of different concentrations of NPK and foliar application of $\left(\mathrm{NH}_{4}\right)_{2} \mathrm{SO}_{4}$ on growth and yield attributes in wheat (Triticum aestivum L.). Pak J Pl Sci.,13, 119-28 (2007)

Jamwal, J. S. Production potential and economics of different crop sequences in rainfed areas of Jammu. Ind $J$ Agro.,45, 269-273 (2000).

Khan, P., M. Y. Memon., M. Imatiaz and M. Aslam: Response of wheat to foliar and soil application of urea at different growth stages. Pak J Bot.,41, 11971204(2009)

Kumar, P., Ali. L., Raza. A., Maqbool. A., Maqbool. S., Rasheed. S and Irum $\mathrm{N}$ :Effect of nitrogen and potassium on nutrient content, uptake and grain yield of wheat. IntJ AgriSci9, 575-78 (2015).

Meena, S. K., S.K. Prasad and M K. Singh: Effect of nitrogen levels and zinc fertilizer scheduling on economic of wheat (Triticum aestivum L.) production in Varanasi district of Uttar Pradesh. International $J \quad P l$ Soil Sci., 17, 1-8(2017).

Mengel, K: Alternative or complementary role of foliar supply in mineral nutrition. Acta Horticulturae, 594, 33-47(2002).

Merwin, H. D and M. Peech: Exchangeability of soil potassium in sand, silt and clay fractions as influenced by nature and complementary cation. Proc Soil SciSoc America., 15, 125-128 (1951).

Narimani, H., Rahimi. M. M., Ahmadikhah. A., Vaezi. B: Study on effect of foliar spray of micronutrient on yield and 
yield components of durum wheat. Arch ApplSci Res., 2,168-176(2010)

Nawaz, F., R Ahmed, E AWaraich, M S Naeem and $R \mathrm{~N}$ Shabbir: Nutrient uptake, physiological responses, and yield attributes of wheat (Triticum aestivum $\mathrm{L}$.) exposed to early and late drought stress. J PlNutri.,35, 961974(2012).

Olsen, S. R., G. V. Cole., F. S. Watanabe and L. A. Dean: Estimation of available phosphorus in soils, extraction with sodium bicarbonate. Cir U. S. Deptt Agri., 939(1954).

Rahman, M. Ataur., M. M. Rahman., M. M. Hasan., Farida. Begum and M. A. Z.Sarker:Effects of foliar application of potassium orthophosphate on grain yield and kernel quality of wheat (Triticum aestivum) under terminal heat stress. Bangladesh J AgriRes.,39, 67-77(2014)

Rogalski, L: Influence of supplementary foliar spray nutrition with plant protection on yield of winter wheat. Acta Scientific Agriculture.,57, 111-18(1994).

Sharma, Peeyush., Vikas Abrol and R. K. Sharma:Impact of tillage and mulch management on economics, energy requirement and crop performance in maize-wheat rotation in rainfed subhumid Inceptisols. India European
J Agro., 34, 46-51(2011)

Singh, Brinder., Anil Kumar, Vikas Abrol, A. P. Singh Jai Kumar, and AshuSharma:Effect of integrated plant nutrient management on pearlmillet (Pennisetium glaucum) productivity in rainfed subtropic Siwalik foothills of Jammu and Kashmir. Ind $J$ Agro.,63, 195-197 (2018)

Strong,W. M: Effect of late application of nitrogen on the yield and protein content of wheat. Aus.J.Exper.Agric.Animal Husb.,22,54-61 (1982)

Subbiah, B. V and G. J. Asija: A rapid method for the estimation of available nitrogen in soils. Curr Sci.,25, 259-260(1956)

Wagan, Z. A., M. Buriro., T. A. Wagan., Z. A. Wagan., S. A. Jamro., Q. U. A. Memon and S. A. Wagan: Effect of Foliar Applied Urea on Growth and Yield of Wheat (Triticum aestivium L). Int J BioChem., 2,185-191 (2017)

Walkley, A. J and C. A. Black: Estimation of organic carbon by chromic acid titration method. Soil Science.,37, 2938(1934).

Yaseen, M., W. Ahmed., M. Arshad., Q.Ali: Response of wheat (Triticum aestivium L.) to foliar feeding of micronutrients. Int JAgro Vet Medi Sci:5,209-220 (2011).

\section{How to cite this article:}

Vikas Abrol, Brinder Singh, Peeyush Sharma, A. P. Singh and Ravinder Chary. 2021. Influence of Foliar Fertilization of Nutrients on Growth, Yield and Economics of Wheat Under Sub-Tropical Rainfed Conditions. Int.J.Curr.Microbiol.App.Sci. 10(08): 673-681. doi: https://doi.org/10.20546/ijcmas.2021.1008.076 